This manuscript has been submitted for publication in COASTAL ENGINEERING. Please note that the manuscript is currently undergoing peer-review and subsequent versions of this manuscript may have slightly different content. If accepted, the final version of this manuscript will be available via the 'Peer-reviewed Publication DOI' link on the right-hand side of this webpage.

Please feel free to contact any of the authors; we welcome feedback. 


\section{A Storm Hazard M atrix combining coastal flooding and beach erosion}

Christopher K. Leaman ${ }^{1 *}$, Mitchell D. Harley ${ }^{1}$, Kristen D. Splinter ${ }^{1}$, Mandi C. Thran ${ }^{1}$, Michael A. Kinsela ${ }^{2,3}$ and lan L. Turner ${ }^{1}$

${ }^{1}$ Water Research Laboratory, School of Civil and Environmental Engineering, UNSW Sydney, 110 King Street, M anly Vale, NSW 2093, Australia

${ }^{2}$ Water, Wetlands and Coast Science, Department of Planning Industry and Environment, Sydney, NSW, Australia

${ }^{3}$ Geocoastal Research Group, School of Geosciences, University of Sydney, Sydney, NSW, Australia

Corresponding author: Christopher K Leaman (c.leaman@unsw.edu.au)

\section{Highlights}

- A new Storm Hazard M atrix integrates coastal flooding and beach erosion along open sandy coasts

- A vertical hazard scale for coastal flooding is adapted from Sallenger's (2000) Storm Impact Scale

- A new horizontal hazard scale for beach erosion is based on the landward translation of key morphological features of the beach and dune profile during a storm

- Applied to two contrasting storm events, the Storm Hazard Matrix identifies the occurrence, location and prevalence of flooding and erosion hazards along the impacted coastlines

- The application of this new framework to operational coastal storm Early Warning Systems is currently being explored 


\section{Abstract}

Coastal storms cause widespread damage to property, infrastructure, economic activity and the environment. Along open sandy coastlines, two of the primary coastal storm hazards are coastal flooding by elevated ocean water levels and beach erosion as the result of storm wave action. At continental margins characterized by a shallow, wide continental shelf, coastal storms are more commonly associated with amplified storm surge and the damaging impacts caused by flooding of low-lying land. In contrast, along margins where the continental shelf is narrow and deep, coastal storm impacts are more often characterized by extensive beach erosion, due to the typically lower magnitude of storm surge but a higher proportion of deepwater wave energy reaching the shoreline. A new Storm Hazard M atrix is presented that integrates these two distinct but inherently linked open coast hazards. The approach is based on the combination of two hazard scales. The first is a 'coastal flooding hazard scale' that follows an established framework in which hazards are predominately driven by the vertical increase in ocean water levels during storms. The second is a storm wave 'beach erosion hazard scale' where hazards are predominately driven by the horizontal recession of the sandy beach and dune. The resulting framework comprises a total of nine unique combinations of flooding/ erosion storm hazard regimes, from which six unified, qualitative indicators of the total storm hazard level ranging from 'Low' to 'Extreme' are defined. Real-world application of the Storm Hazard Matrix is explored at contrasting coastlines for two major storm events, encompassing an extratropical cyclone that impacted the coastline of southeast Australia in June 2016, and Hurricane Ivan that impacted the Gulf Coast of the United States in 2004. The new approach is shown to identify and distinguish between the severity of localized coastal flooding and/ or coastal erosion, as well as provide enhanced insight to the nature, magnitude and alongshore variation of coastal storm hazards along the impacted coastline. Within the context of disaster risk reduction, preparedness and operational early warning, implementation of the Storm Hazard Matrix has the potential to deliver robust evaluations of storm hazards spanning a wider variety of both wave-dominated and surge-dominated coasts.

\section{Keywords}

Coastal erosion; Storm surge; Coastal hazards; Storm Impact Scale; Erosion Hazard Scale; Hurricane Ivan; East Coast Low; Storm hazard forecasting; Early Warning Systems 


\section{Introduction}

There are few regions of the earth's surface more vulnerable to the damaging impacts of storms than the narrow strip of the coastal zone (Harley, 2018). Globally, storms rank as one of the deadliest weather-related natural hazards (Whalstrom and Guha-Sapir, 2015). Coastal storms cause widespread damage to property, infrastructure, economic activity, and the environment. Along open sandy coastlines, beach and dune systems provide a first line of defence against the damaging impacts of the ocean. Two of the primary coastal storm hazards are coastal flooding by elevated ocean water levels (or 'storm surge') resulting in flooding of low-lying land; and beach erosion caused by storm wave action. Individually or combined, both flooding and erosion pose a significant threat to settled coasts worldwide (Rueda et al., 2017; M entaschi et al., 2018).

Understanding the nature and evolution of storm-induced coastal flooding and beach erosion is necessary to inform and enact appropriate and timely disaster preparedness (UNISDR, 2006). For example, coastal flooding as the result of ocean overtopping of wave overtopping and dune breaching may escalate quickly within a matter of minutes to hours, leading to rapid inundation of potentially extensive areas of low-lying coastal land. Alternatively, storm wave beach erosion resulting in the undermining and failure of adjacent beachfront infrastructure, typically evolves progressively over comparatively longer timescales extending to hours and days. The differing nature of these coastal storm hazards also means that the impacts of erosion are generally restricted to the immediate vicinity of the coast; with the post-storm natural recovery of the impacted beachfront typically spanning months to years (e.g. Morton et al., 1994; Phillips et al., 2019). This contrasts to coastal flooding of potentially much larger areas of land that more typically subsides in hours to days.

Coastal setting is a key factor that determines ocean hazards during a storm. Along continental margins characterized by a shallow, wide continental shelf, coastal storms are more commonly associated with amplified storm surge and the damaging impacts caused by flooding of low-lying land. In contrast, along margins where the continental shelf is narrow and deep, coastal storm impacts are more often characterized by extensive beach erosion, due to the typically lower magnitude of storm surge but a higher proportion of deepwater wave energy reaching the coastline. The relative contributions of these two hazards is therefore dependent on both the event-specific hydrodynamic conditions (primarily wave energy and water levels) and the site-specific morphological characteristics of the impacted coastline (Harley et al., 2017).

Along open sandy coasts, storm-induced coastal flooding and beach erosion have the potential to be inherently linked, and it is therefore beneficial to consider them jointly (Pollard et al., 2019). As an illustration, prolonged storm wave attack over several consecutive high tides may progressively erode 
a dune sand barrier system. Once a threshold in dune depletion is reached, this may then trigger rapid and extensive coastal flooding as the defence provided by the dune is compromised. Understanding the interdependency of storm-induced coastal flooding and beach erosion is therefore important for assessing overall risk (Hillier et al., 2020).

Figure 1 synthesizes this interdependency to hydrodynamic conditions and morphological setting that together determine the nature and severity of coastal flooding and beach erosion hazards at the open coast. Increases in storm surge are likely to amplify the coastal flooding hazard, whereas higher wave energy and/or longer storm durations typically result in an increase to the erosion hazard (Dolan and Davis, 1992; Harley et al., 2017). In combination with these factors, the site-specific morphological setting is also important. Cliffed coastlines, for example, are more resistant to flooding and erosion, while low-lying, sandy coastal barriers are more vulnerable. Given the complexity of the hydrodynamic and morphological factors involved in assessing coastal storm hazards, a conceptual framework that can be usefully applied to categorize the nature, magnitude and interaction of both potential hazards is beneficial.

\section{Hydrodynamic conditions}

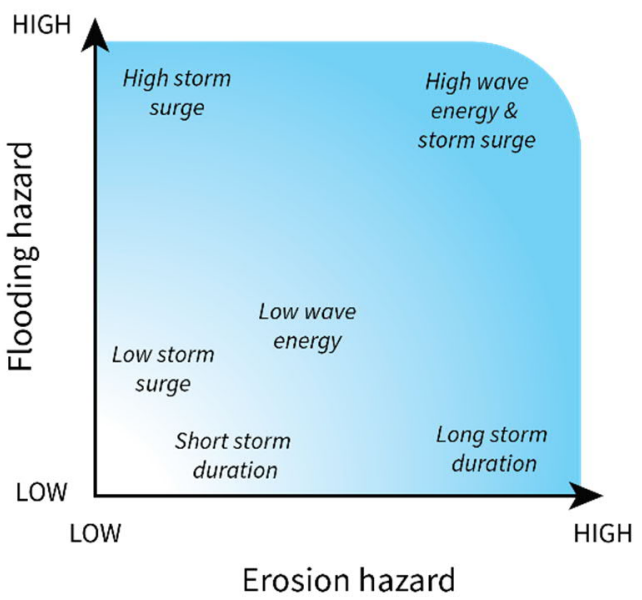

\section{Morphological setting}

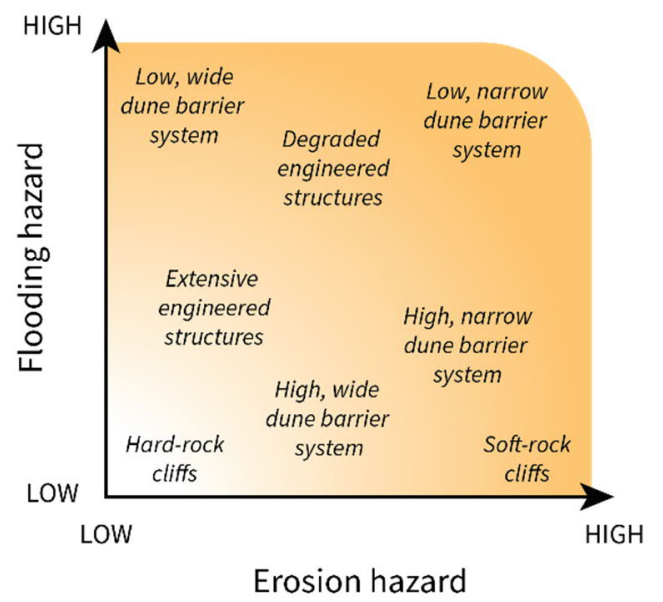

Figure 1: Along open sandy coastlines, both hydrodynamic conditions (left) as well as morphological setting (right) combine to determine the nature and severity of the coastal flooding and beach erosion hazards during storms. (Adapted from Pollard et al., 2019).

There are a range of existing approaches to categorize or quantify the severity of coastal flooding or beach erosion along open coasts due to storms. The most widely used categorical approach is the 'Storm Impact Scale' presented by Sallenger (2000). As is discussed further in the next section, this approach is based on four distinct 'impact regimes' that are defined by the vertical elevation of the maximum Total Water Level during a storm, relative to specific morphological features of the local beach and dune profile. Notably, storm wave energy is not considered directly in this schema. Several 
alternative approaches to calculating or ranking coastal storm impact severity also exist, based on cumulative storm wave energy (e.g. Dolan and Davis, 1992; Harley et al., 2009; M endoza et al., 2011), the cumulative storm tide residual (Zhang et al., 2002), or hybrid methods based on storm surge, wave height and/or storm duration (e.g. Kriebel et al., 1996; M iller and Livermont, 2009). Notably, with the exception of Sallenger (2000) all these approaches consider only the hydrodynamic conditions of a storm and do not consider the local subaerial beach and dune conditions. Another approach is to focus only on storm impacts to dune systems and whether the integrity of this first line of defence is compromised (Judge et al., 2003; Armaroli et al., 2012).

Having established that elevated ocean water levels, storm waves and local morphology will all determine the ocean impacts of a storm along open sandy coastlines, and that coastal flooding and beach erosion are two distinct hazards that are also inherently linked, presented here is an integrated Storm Hazard M atrix that aims to synthesise these multiple factors. Building from Sallenger's (2000) approach that is based on a vertical scale of storm impacts defined by elevated ocean water levels, a new horizontal dimension is introduced to explicitly include wave-induced beach erosion and its contribution to the total storm hazard. Application of the resulting Storm Hazard M atrix is explored along contrasting coastlines for two major storm events, encompassing an extratropical cyclone that impacted the coastline of southeast Australia in June 2016, and Hurricane Ivan that impacted the Gulf Coast of the United States in 2004. With coastal storm hazard preparedness and operational early warning a growing focus worldwide (e.g. Harley et al., 2012, 2016; Jimenez et al., 2018; Lerma et al., 2018; Armaroli and Duo, 2018; Doran et al., 2019; Stokes et al., 2019; Winter et al., 2020) additional discussion is provided of important considerations when applying the Storm Hazard $M$ atrix to differing coastal settings, as well as the necessary data requirements for implementation of this new approach to real-time storm hazard forecasting.

\section{A combined coastal flooding and beach erosion hazard matrix}

The new Storm Hazard Matrix developed and presented here integrates the two distinct but also inherently linked hazards of coastal flooding and beach erosion that occur along open sandy coastlines. The approach combines two hazard scales: a 'coastal flooding hazard scale' that follows an established framework in which hazards are predominately driven by the vertical increase in ocean water levels during storms; and a storm wave 'beach erosion hazard scale', where hazards are predominately driven by the horizontal recession of the sandy beach and dune system. It is noted that for armoured coastlines, erosion hazards are likely to be less significant and other more suitable approaches to categorizing the total storm hazard should be considered (e.g. Van der Meer et al., 2018). Alternative causes and mechanisms of coastal land flooding during storms - for example, rainfall 
resulting in increased water levels at the downstream boundary of rivers and estuaries - are also outside the scope of the framework presented.

\subsection{Coastal Flooding - vertical hazard scale}

The characterization of coastal flooding hazards is adapted from Sallenger's (2000) well-known and widely-applied Storm Impact Scale. Originally developed to distinguish hurricane storm impacts along U.S. Atlantic and Gulf coast barrier islands, the Storm Impact Scale has since been used to characterize the impacts of storms at open coast beach and dune systems worldwide (e.g. Stockdon et al., 2007; Houser et al., 2008; Roelvink et al., 2009; McCall et al., 2010; Castelle et al., 2015). With this existing framework as the starting point, the 'flooding hazard scale' used here is based on the same elevated ocean water level criteria and associated impact level regimes; however, the key difference is that an expanded range of morphological changes are considered separately by a second 'beach erosion hazard scale' (Section 2.2).

The Total Water Level (TWL) during a storm event is the vertical sum of astronomical tide, storm surge, wave setup and wave runup. To distinguish four distinct storm impact regimes, Sallenger (2000) considered two representative high and low vertical TWL elevations associated with an individual storm; termed peak high TWL (Z $\left.Z_{T w L, h i g h}\right)$ and peak low TWL $\left(Z_{T W L, l o w}\right)$. Based on these upper and lower TWLs relative to the local elevations of the dune crest $\left(Z_{\text {crest }}\right)$ and dune toe $\left(Z_{\text {toe }}\right)$, the same terminology as Sallenger (2000) is now adapted to define four distinct coastal flooding hazard regimes, using the following criteria:

- Swash regime $\left(Z_{T w L, h i g h}<Z_{\text {toe }}\right)$ : This occurs when the peak high TWL does not reach the dune toe and therefore the swash is confined to the beach area. This represents the lowest level of coastal storm flooding hazard, with a safe corridor for access or amenity maintained between the dune and shoreline.

- Collision regime $\left(Z_{\text {toe }} \leq Z_{T W L \text {,high }}\right)$ : The peak high TWL is impacting the dune, resulting in the adjacent beach area being intermittently or continuously submerged. This represents the second level of flooding hazard, as a dry corridor between the dune and shoreline is now removed.

- Overwash regime $\left(Z_{T W L, \text { low }} \leq Z_{\text {crest }}<Z_{T W L \text {,high }}\right)$ : This occurs when the dune crest is intermittently overtopped. As a result, assets and property behind the dune may be subject to potential flooding. Flooding hazards may also be exacerbated during long-duration events or if inadequate drainage is provided. 
- Inundation regime $\left(Z_{\text {crest }} \leq Z_{T W L, \text { low }}\right)$ : The dune crest is constantly submerged. This represents the highest and most severe level of coastal storm flooding hazard for the open coast.

A schematic of these four coastal flooding regimes that are each based on vertical elevation criteria is presented in Figure 2 (left panel).

\subsection{Beach Erosion - horizontal hazard scale}

Beach erosion caused by the removal of sand from the beach and dune by storm wave action may be exacerbated by elevated ocean water levels (Pollard et al., 2019). However, this association between higher TWL and larger waves, and their relative contribution to the total storm hazard, varies significantly along coastlines worldwide. To reiterate, factors such as the width and depth of the continental shelf control the local magnitude of storm surge and ocean wave energy that reaches the coast (Cohn et al., 2019; Serafin et al., 2019). To accommodate this, the approach adopted here is to first characterize these distinct hazards separately, then combine to determine their joint contribution to the total storm hazard at any specific location.

To compliment the 'coastal flooding scale' outlined in Section 2.1, a second 'erosion hazard scale' is now developed. In contrast to the vertical elevation criteria used to define the four flooding hazard regimes, the definition of four new erosion hazard regimes is based on the horizontal and landward translation of key features of the beach and dune profile during a storm. Beach width change ( $\left.\Delta \mathrm{X}_{\text {width }}\right)$ is defined as the change in the horizontal distance from the pre-storm dune toe to the shoreline, typically represented by a suitable elevation contour such as mean sea level or mean high water. A beach width change threshold ( $X_{\text {threshold }}$ ) then distinguishes between 'minor' and 'substantial' beach width narrowing. This threshold parameter is user-defined, so that it is adaptable and appropriate to a particular coastal setting or application. For example, a coastal researcher may choose to base this threshold on the overall magnitude or percentage of horizontal shoreline change. In contrast, a coastal manager may define this threshold by the post-storm width of the beach relative to a coastal asset such as a building or a walkway. When the erosive action of storm waves extends landward to the dune, dune toe retreat $\left(\Delta \mathrm{X}_{\text {toe }}\right)$ is defined as the change in horizontal distance at the elevation of the pre-storm dune toe. Finally, dune crest retreat $\left(\Delta \mathrm{X}_{\text {crest }}\right)$ denotes the horizontal distance between the pre-storm dune crest and the post-storm dune crest. This parameter indicates whether erosion and/or coastal flooding protection provided by the dune has been compromised.

Applying the criteria above, the resulting erosion hazard scale shown in Figure 2 (right panel) now categorizes four new beach erosion hazard regimes: 
- Minor beach narrowing regime $\left(\Delta X_{\text {width }}<X_{\text {threshold, }} \Delta X_{\text {toe }}=0\right)$ : As the lowest level of beach erosion hazard, the reduction in beach width does not exceed the user-defined threshold $X_{\text {threshold, }}$ and no changes to the dune system are observed.

- Substantial beach narrowing regime $\left(\Delta X_{\text {width }} \geq X_{\text {threshold, }} \Delta X_{\text {toe }}=0\right)$ : The reduction in beach width exceeds the user-defined threshold, but the dune remains intact. From a coastal management perspective, a suitable threshold can be selected so that this erosion hazard level will indicate that the buffer provided by the beach is reduced, and the dune system may be vulnerable to subsequent storms.

- Dune face erosion regime $\left(\Delta \mathrm{X}_{\text {toe }}<0, \Delta \mathrm{X}_{\text {crest }}=0\right)$ : This occurs when sediment landward of the dune toe is eroded, but the dune crest is not impacted. Post-storm return of the dune buffer to pre-storm conditions may take of the order of months to years to fully recover.

- Dune retreat regime $\left(\Delta \mathrm{X}_{\text {crest }}<0\right)$ : This represents the highest level of erosion hazard resulting in impacts to the landward side of the dune crest and any assets or other infrastructure that may be located in this area. If the dune crest is also lowered, then flooding hazards may be exacerbated.

Flooding hazard regimes adapted from Sallenger (2000)

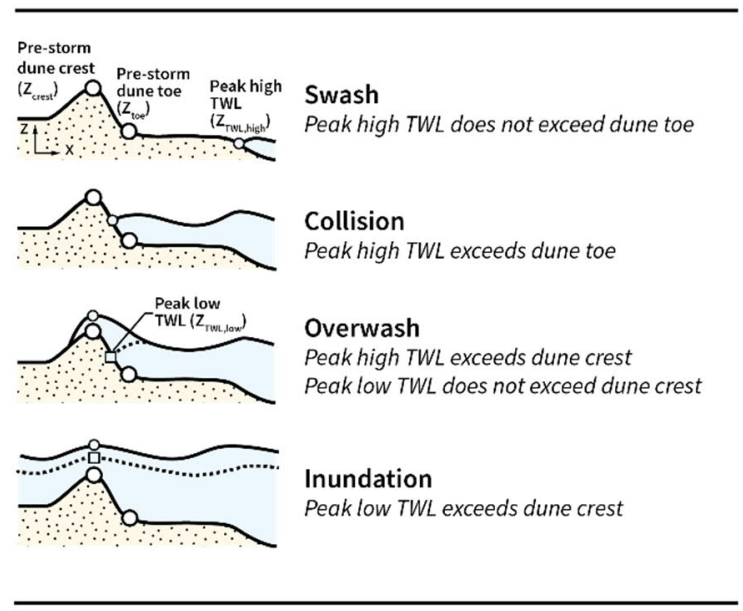

\section{Erosion hazard regimes}

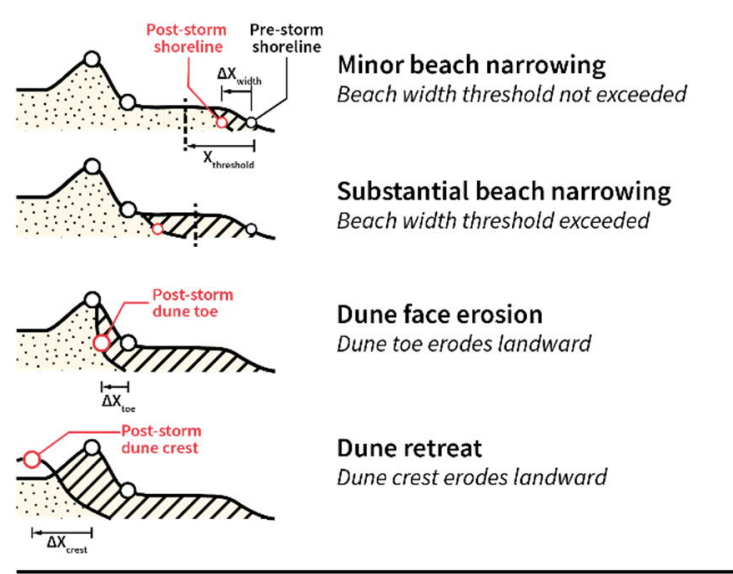

Figure 2: Left: Coastal flooding (left) and beach erosion (right) hazard scales and the criteria used to distinguish between individual hazard regimes. Peak high TWL $\left(Z_{T W L}\right.$ igh $)$ and peak low TWL $\left(Z_{T W L, \text { low }}\right)$ are respectively defined as the representative high and low water levels and include the effects of astronomical tides, storm surge, wave setup and wave runup. The pre-storm dune is parameterized by two features: the dune crest elevation $\left(Z_{\text {crest }}\right)$ and dune toe elevation $\left(Z_{\text {toe }}\right)$. The change in beach width $\left(\Delta X_{\text {width }}\right)$ is defined by the change in horizontal distance between the pre-storm dune toe position and shoreline. The beach width threshold ( $\left.X_{\text {threshold }}\right)$ is a user-defined threshold defined as a horizontal distance from the pre-storm shoreline position. Changes to the dune toe position $\left(\Delta \mathrm{X}_{\text {toe }}\right)$ and dune crest $\left(\Delta \mathrm{X}_{\text {crest }}\right)$ position are defined by the horizontal distance between the pre-storm and post-storm dune toe and crest respectively. 


\subsection{Combined Storm Hazard M atrix}

The Storm Hazard M atrix shown in Figure 3: The Storm Hazard M atrix integrates coastal flooding and beach erosion hazards into a single framework. A total of nine individual combinations of flooding and erosion hazard scale regimes are identified along sandy, erodible coastlines. Recognising that the expected damage caused will vary and require differing management responses, six unified, qualitative indicators of the total storm hazard level ranging from Low to Extreme are defined. integrates the coastal flooding and beach erosion hazard scales outlined above into a single, unified framework. The vertical dimension is defined by the four flooding hazard regimes (Section 2.1) adapted from Sallenger (2000). The horizontal dimension is defined by the four beach erosion hazard regimes based on landward recession of the shoreline, dune toe and dune crest (Section 2.2). The result is the Storm Hazard M atrix shown in Figure 3 defining a total of nine potential coastal storm hazards along open, sandy coastlines. Also recognising that the expected damage caused will vary and require differing management responses, six unified, qualitative indicators of the total storm hazard level are now identified:

- Low storm hazard level: When a combination of swash and minor beach narrowing regimes are present there is minimal hazard presented by the storm. Typically, no action is required by the coastal manager.

- Moderate storm hazard level: If erosion hazards escalate and substantial beach narrowing occurs in combination with the swash flooding regime, amenity and access across the beach may be reduced. In addition to assessing public safety at the beach, coastal managers may become "alert" in case storm conditions worsen.

- High storm hazard level: When dune face erosion occurs, whether by wave impact in the collision regime or dune undermining in the swash regime, coastal managers will likely adopt a heightened state of alert. In particularly vulnerable locations or known erosion hotspots, more detailed modelling may be necessary to gain a more quantitative understanding of the hazard.

- Very High storm hazard level: Once dune retreat erosion occurs (either in the swash or collision flooding regimes) or the overwash regime causes intermittent overtopping of the dune crest, assets located behind the dune may become at risk to both erosion and flooding. Once storm events reach this severity, complex feedback loops between flooding and erosion hazards are more prevalent (e.g. dune crest lowering causing further flooding) and active hazard mitigation actions by the coastal manager are likely to be warranted. 
- Severe storm hazard level: When overwash and dune retreat regimes are occurring simultaneously, the area behind the dune may be at exacerbated risk of both erosion and flooding hazards. The exposure and vulnerability of coastal assets may warrant a significant emergency response.

- Extreme storm hazard level: Combination of the two end-scale inundation and dune retreat flooding and erosion hazard regimes has the greatest potential to cause major damage at the coastline. This threat would be of the highest concern to coastal managers, and likely require extensive pre-storm preparedness, implementation of hazard mitigation measures and poststorm recovery operations across the impacted areas.

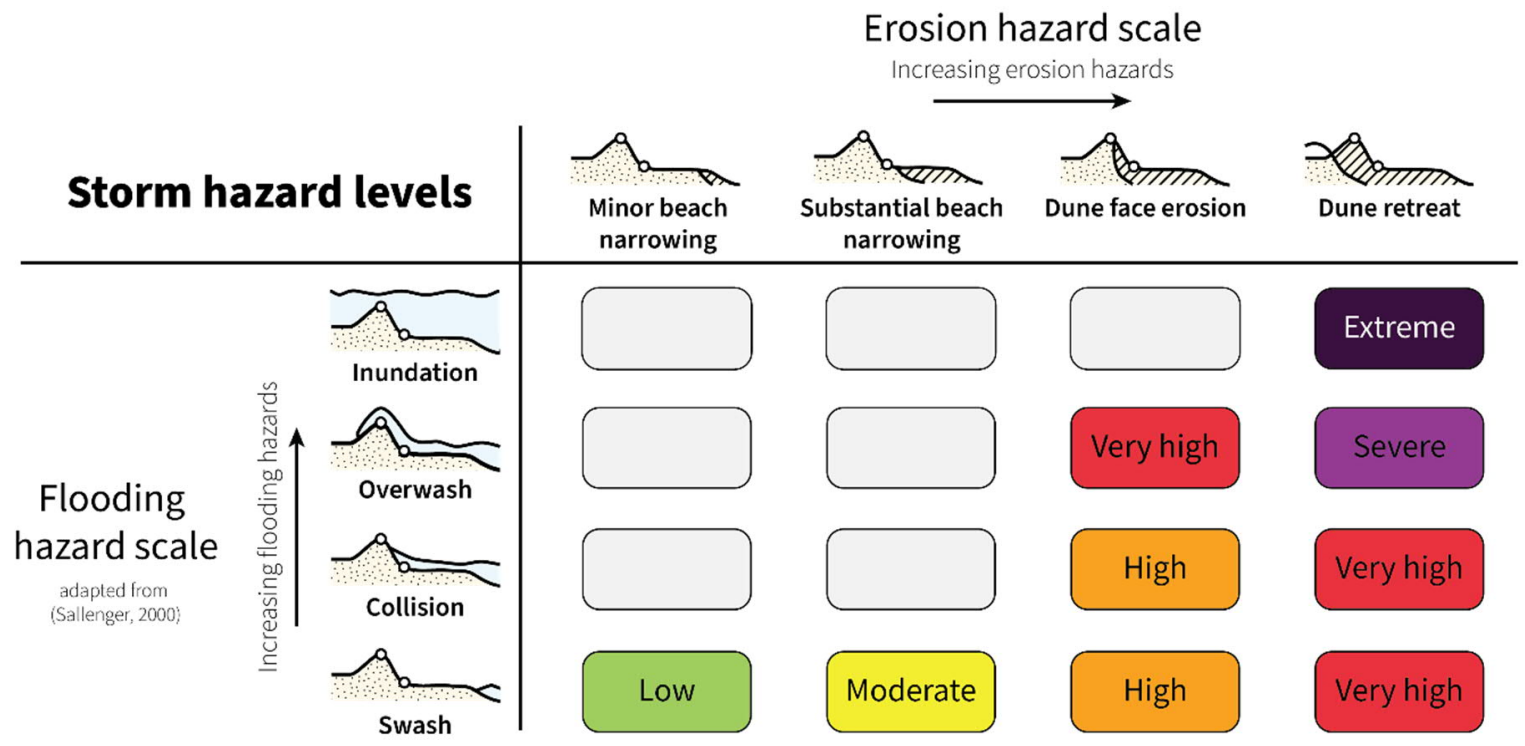

Figure 3: The Storm Hazard M atrix integrates coastal flooding and beach erosion hazards into a single framework. A total of nine individual combinations of flooding and erosion hazard scale regimes are identified along sandy, erodible coastlines. Recognising that the expected damage caused will vary and require differing management responses, six unified, qualitative indicators of the total storm hazard level ranging from Low to Extreme are defined.

\section{Storm Hazard M atrix applied to real-world storm events}

Real-world application of the integrative Storm Hazard M atrix is illustrated here for two contrasting coastal storm events. These examples demonstrate how the framework can be used to distinguish the differing nature and alongshore variability of storm-induced coastal hazards within the impacted region, and if used within the context of a forecast, can potentially inform the targeted preparedness of emergency managers. The first coastal storm was an intense extratropical low-pressure system that occurred in southeast Australia in April 2016, and the second is Hurricane Ivan and its impacts to Santa Rosa Island, Florida USA in September 2004. These two events demonstrate how differences in hydrodynamic storm conditions and coastal morphological setting can result in quite different hazards and their distribution alongshore. The extratropical low pressure event in SE Australia waS 
characterized by prolonged, high energy wave conditions along an embayed coastline that exhibits a narrow and deep continental shelf, primarily resulting in beach erosion hazards observed (Harley et al., 2017). In contrast, the Hurricane Ivan event in NW Florida was associated with high storm surge that primarily exposed the linear, low-lying, barrier island system located in the shallow coastal region of the Gulf of M exico, to coastal flooding hazards (M cCall et al., 2010; Plant and Stockdon, 2012). The differing regional settings and storm characteristics of these two events are outlined below, resulting in quite different outcomes when the Storm Hazard M atrix is applied.

\subsection{Regional settings, storm characteristics and coastline impact observations}

Between 4-7 June 2016 an intense extratropical storm (known locally as an 'East Coast Low') impacted more than a $1000 \mathrm{~km}$ of the southeast Australia coastline. The region considered here that is located in the state of New South Wales (NSW) is characterized by embayed sandy beaches separated by rocky headlands. Exacerbated storm impacts were observed due to the anomalous easterly direction of the storm combined with the coincidence of the storm peak with highest astronomical tides. Immediate pre- and post-storm aerial LIDAR surveys of approximately $178 \mathrm{~km}$ of sandy beaches between Sydney and Coffs Harbour were conducted (Figure 4a). Using these datasets, pre- and post-storm beach and dune transects were extracted at every $100 \mathrm{~m}$ alongshore. Wave conditions at the $10 \mathrm{~m}$ isobath at each transect were estimated using multiple, nested WAVEWATCH III models while still water levels (i.e., astronomical tide +storm surge) were recorded by five tide gauges across the region. An example wave timeseries, water level timeseries and pre-storm transect are shown in Figure 4c, Figure $4 d$ and Figure $4 \mathrm{e}$, respectively. Further details of the event, LiDAR data and wave modelling are described in Harley et al. (2017).

On 16 September 2004 Hurricane Ivan made landfall as a Category 3 hurricane, overwashing large portions of Santa Rosa Island, a low-lying barrier island located on the Northern Florida Panhandle, USA. Pre- and post-storm aerial LIDAR surveys were obtained spanning approximately $70 \mathrm{~km}$ along the seaward side of the island (Figure 4b) with pre- and post-storm transects extracted every $100 \mathrm{~m}$ alongshore. Wave conditions and water levels at the $20 \mathrm{~m}$ isobath corresponding to each transect were estimated using an XBeach model of the hurricane event. An example wave timeseries, water level timeseries and pre-storm transect are also shown in Figure 4c, Figure $4 d$ and Figure 4e, respectively. Further details of the event, LiDAR data and modelling are described in McCall et al. (2010) and Plant and Stockdon (2012). 

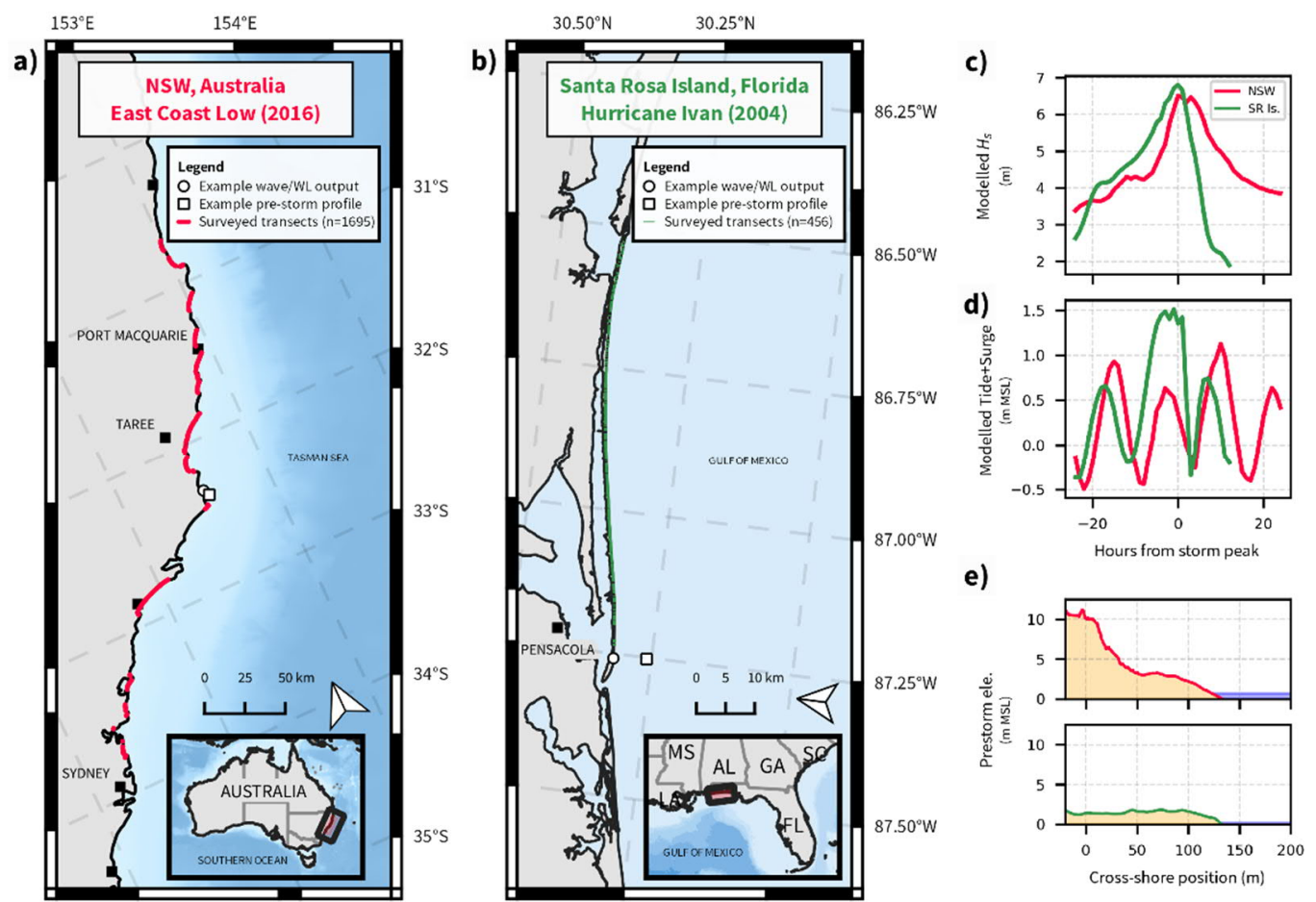

Figure 4: Regional setting and locations of surveyed transects in (4a) NSW for the 2016 East Coast Low event and (4b) at Santa Rosa Island for the 2004 Hurricane Ivan event. 4c compares a sample inshore timeseries of the modelled significant wave height at the $10 \mathrm{~m}$ isobath in NSW and the $20 \mathrm{~m}$ isobath at Santa Rosa Island. The modelled astronomical tide combined with storm surge at both sites is shown in $4 \mathrm{~d}$. $4 \mathrm{e}$ contrasts measured pre-storm topographic profiles at the indicated locations for two transects that are representative of each region.

Differences in the morphological setting and hydrodynamic conditions between the two regional locations and these two storm events are apparent in Figure 4. While maximum wave heights during the two events were quite similar, the NSW coastline was subjected to a substantially longer duration of high energy storm wave conditions (Figure 4c). At Santa Rosa Island elevated water levels at the peak of the storm were exacerbated by pronounced storm surge that increased then subsided relatively quickly (Figure $4 d$ ). Along the NSW coastline, storm surge was relatively minor; the coincidence of the storm with highest astronomical tides was the main driver of elevated water levels. The pronounced differences in the morphological setting of the two regions is demonstrated in Figure 4e. Santa Rosa Island is typical of linear, low-lying barrier island systems on the U.S. East and Gulf coasts that experience large storm surges (Zhang et al., 2002). The embayed NSW coastline on the other hand, generally consists of a more substantial barrier dune system with the occurrence of storm surge limited by the region's steep and narrow continental shelf (M clnnes and Hubbert, 2001).

Using the available $100 \mathrm{~m}$ alongshore beach and dune profiles, the pre- and post-storm dune toe and dune crest positions were identified manually, then compared to the local waves and water levels at each transect to classify the erosion hazard regime at every $100 \mathrm{~m}$ alongshore. The cross-shore position of the shoreline at mean high water level was selected to determine pre- and post-storm beach width. For the purpose of illustration, a $30 \%$ change relative to the pre-storm beach width was 
adopted as the threshold criteria to distinguish between 'minor' and 'substantial' beach narrowing. This is of course arbitrary, and as previously noted in Section 2.3, this threshold condition is defined by the user so that it best suits a location-specific management and/or research application. Since no direct TWL observations during either event were obtained, flooding hazard regimes at each transect were estimated by summing the tide and measured (NSW) or modelled (Santa Rosa) storm surge (Figure 4d) with an empirical estimate for combined wave setup and runup, using the widely-used model of Stockdon et al. (2006). The peak high TWL and peak low TWL (refer Section 2.1 and Figure 2) were estimated at each transect based on the $2 \%$ runup exceedance. Adapting the approach outlined in Stockdon et al. (2007), classification of the coastal flooding regimes for every $100 \mathrm{~m}$ alongshore transect were obtained.

\subsection{Comparison of Storm Hazard M atrix classification}

A synthesis is presented in Figure 5 that shows the occurrence of each of the coastal flooding and beach erosion hazard regimes, as well as the relative prevalence of each resulting storm hazard level for the NSW 2016 and Santa Rosa 2004 coastal storms. For the NSW event, the most common storm hazard level is high (47\%), which combined with moderate (29\%) and low (20\%) accounted for $96 \%$ of the total region. In contrast, for the Santa Rosa event the great majority of the hazard level is severe (72\%). While both events were considered to be a serious threat to their respective communities, the higher storm hazard levels at Santa Rosa Island match the extensive damage to property and infrastructure that was reported for this event (DEP Florida, 2004), compared with NSW where impacts were observed to be much more localized (NSW DJOEM , 2016).

Separately examining the flooding and erosion hazard regimes for both these events (Figure 5, left and middle panels) provides additional insight. For example, at the regional scale, storm hazard levels predominantly in the range of low to high occurred along the NSW coast during the $2016 \mathrm{ECL}$ event and were primarily the result of beach narrowing and dune face erosion. Contrasting to this, the very high to extreme storm hazard levels along Santa Rosa Island during Hurricane Ivan were associated with coastal flooding hazards as the result of dune overwash. Additionally, the Storm Hazard Matrix approach can usefully distinguish within the single collision flooding regime between the quite distinct hazard levels of high (dune face erosion) and very high (dune retreat).

Figure 6 and Figure 7 provide both regional and more localized overviews of the geographic distribution of storm hazards for these two storm events, demonstrating the different types of impacts along their respective coastlines. Both figures display the storm hazard level at every $100 \mathrm{~m}$ alongshore spanning the region (left panel). A more localized view of the coastline is also shown, (top right panel) where the individual flooding and erosion hazard as well as the resulting storm hazard 
level, are indicated. To aid interpretation, also included in both these figures are post-storm photos of the impacted coastline and corresponding pre- and post-storm beach and dune profiles at the indicated locations alongshore. Narrabeen-Collaroy, a NSW beach where the intra-embayment erosion impacts varied significantly, is shown in Figure $6 \mathrm{~b}$. While the same collision flooding hazard regime occured at both locations along the beach shown in Figure $6 c$ and Figure $6 \mathrm{~d}$, the southern location experienced a very high hazard level due to dune retreat. This compares to a high hazard level at the more northern location due to lesser dune face erosion. The resulting contrast in the degree of damage to beachfront homes that is evident in Figure $6 c-d$ is not adequately captured by considering only the flood hazard regimes defined by the vertical reach of the TWL. At Santa Rosa Island (Figure 7a) a more uniform very high to severe alongshore hazard level was observed. Referring back to the Storm Hazard Matrix in Figure 7, the transects at Navaree Beach (Figure 7b) and photos of two examples locations (Figure 7c-d) show the damaging impacts caused by the predominance of the flooding hazard overwash regime and erosion hazard dune retreat regime, resulting in the classification of very high to severe hazard levels.

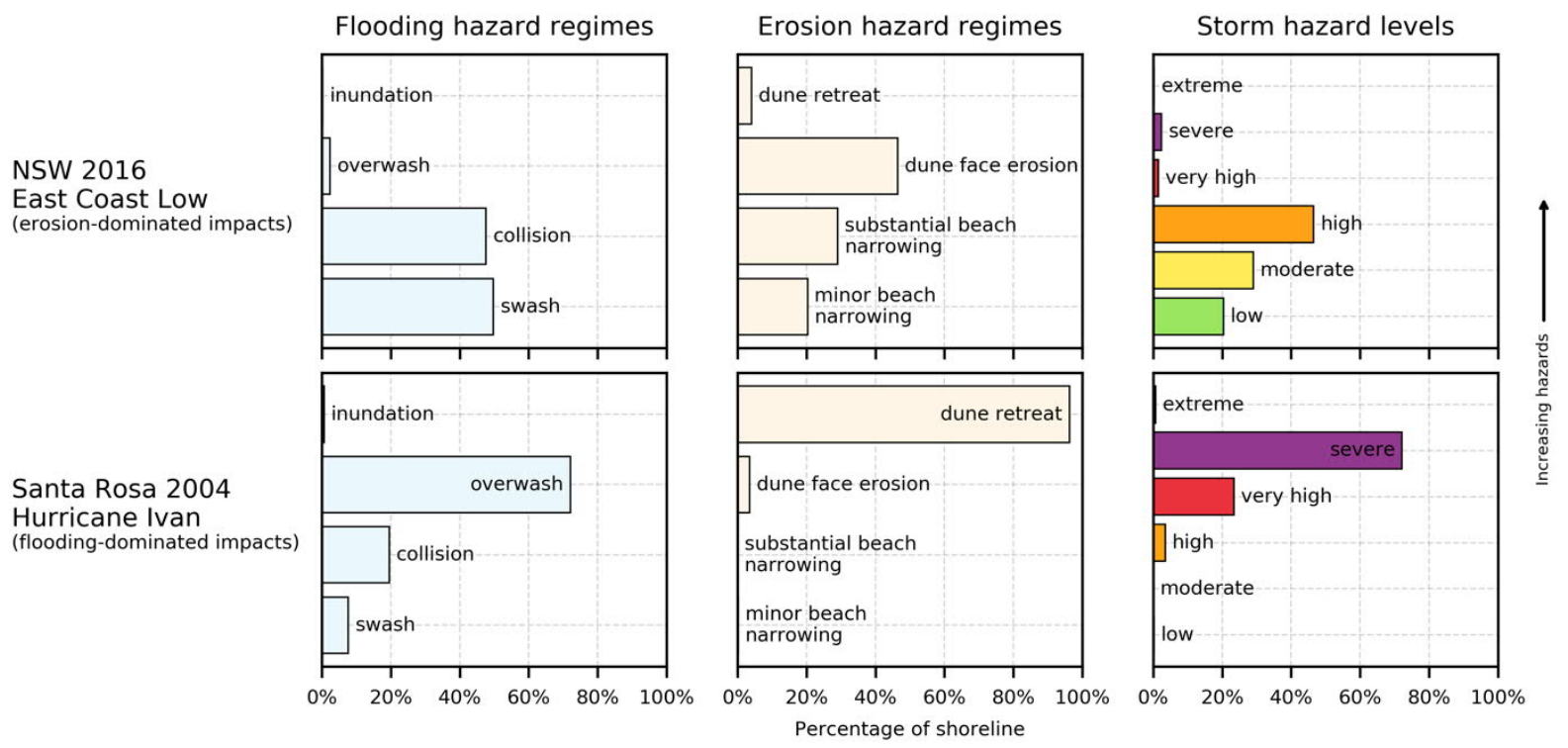

Figure 5: Distribution of flood hazard levels (left column), erosion hazard levels (center column) and combined storm hazard levels (right column) on the NSW coastline for the 2016 East Coast Low event (top row) and at Santa Rosa Island for the 2004 Hurricane Ivan event (bottom row). 

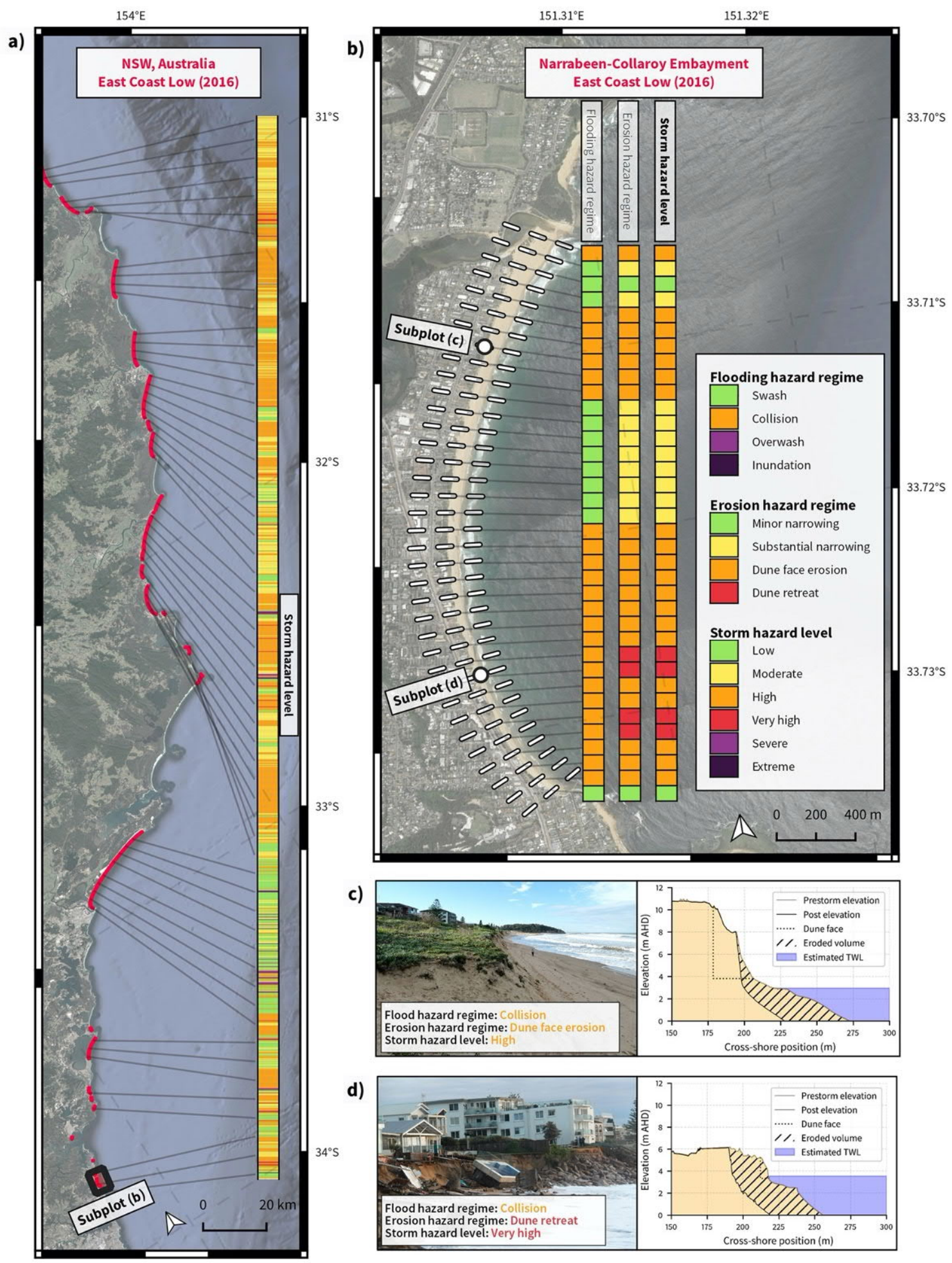

c)

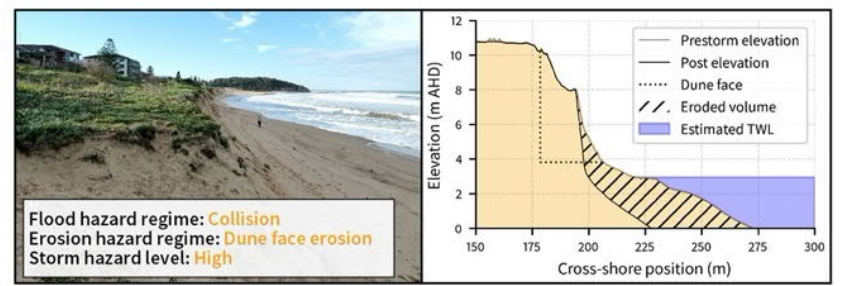

d)

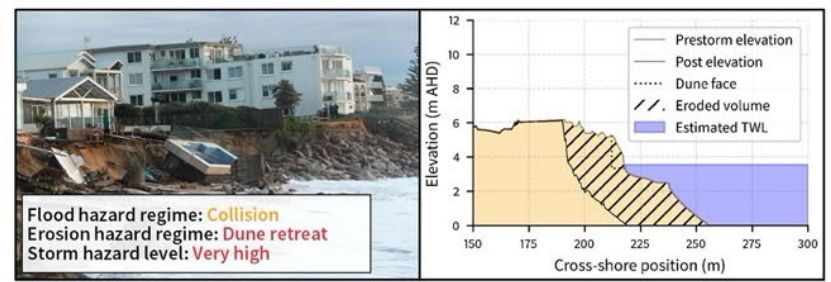

Figure 6: Regional (a) and more localized (b) observations at $100 \mathrm{~m}$ alongshore intervals of coastal flooding and beach erosion storm hazard regimes and the resulting storm hazard levels along the NSW coastline for the 2016 East Coast Low event. Photos and the pre- and post-storm survey transects ( $c \& d$ d) at the indication locations show the differing levels of damage to beachfront homes. This correctly corresponds to the very high hazard level at the more southern location, compared to a high hazard level at the northern location. Notably, this intra-embayment variability is not adequately captured by flood hazard regimes defined by the vertical reach of the TWL [Photos courtesy of UNSW Water Research Laboratory]. 

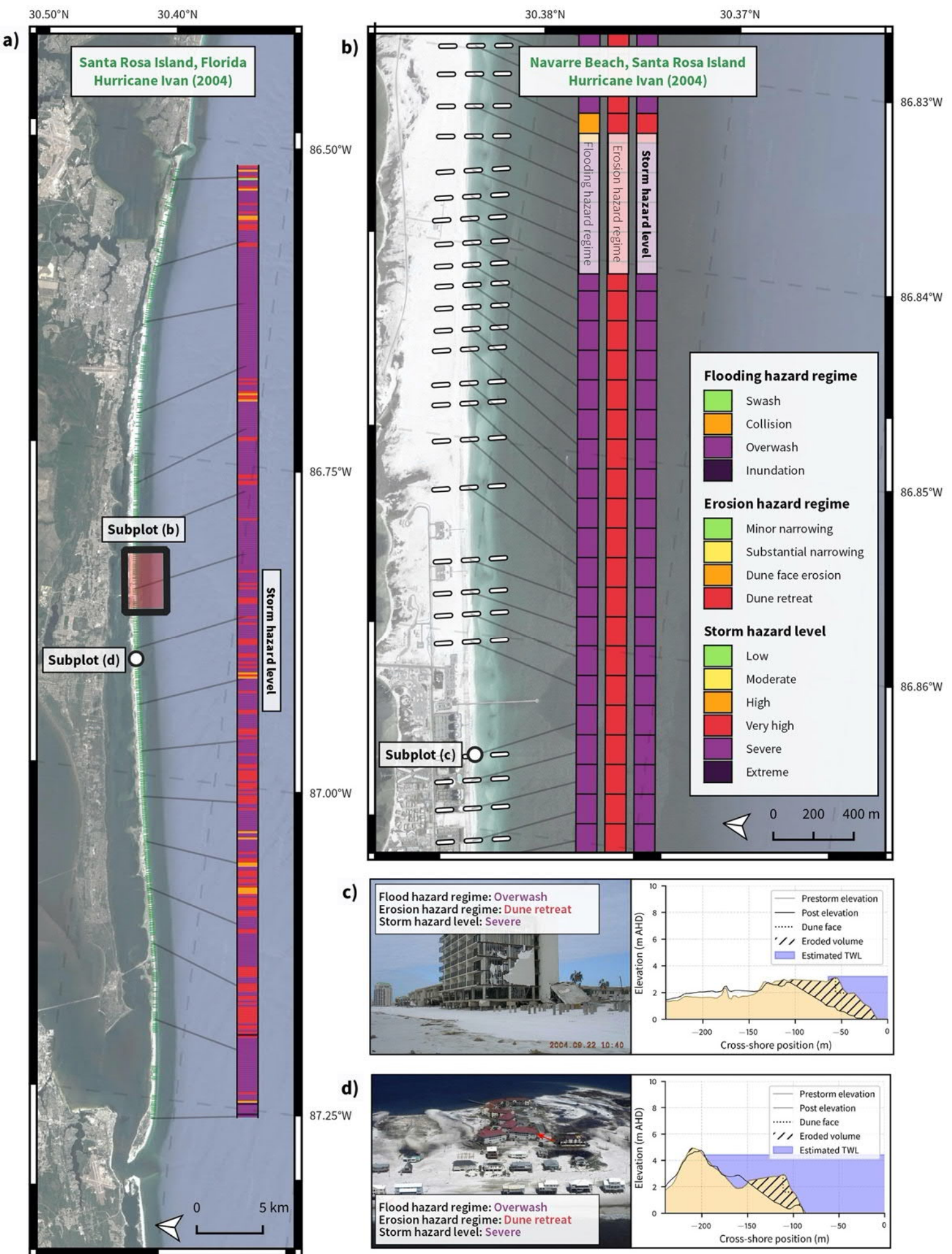

c)

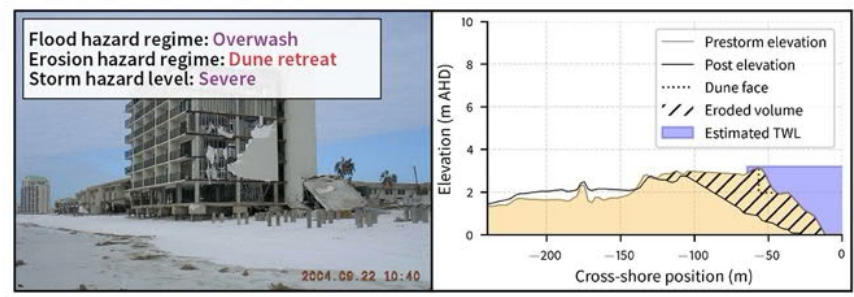

d)

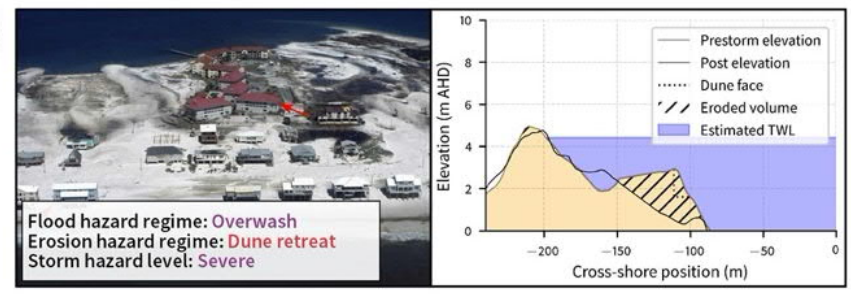

Figure 7: Regional (a) and more localized (b) observations at approximately $100 \mathrm{~m}$ along-shore intervals of coastal flooding and beach erosion storm hazard regimes and the resulting storm hazard levels along the Santa Rosa coastline for the 2004 Hurricane Ivan event. Photos and the pre- and post-storm survey transects ( $c \& d$ ) at the indication locations show the damaging impacts caused by the predominance of the flooding hazard overwash regime and erosion hazard dune retreat regime, resulting in the classification of very high to severe hazard levels [Photos courtesy of USGS and State of Florida]. 


\section{Synthesis and future directions}

The Storm Hazard M atrix summarized in Figure 3 applied in the previous section to two contrasting storm events along very different coastal settings in Australia and the USA, demonstrates the potential utility and benefits of assessing coastal flooding and beach erosion hazard regimes within a single framework to categorise an integrative storm hazard level. A particular advantage of this approach is that no initial assumption is necessary of the relative dominance of coastal flooding versus coastal erosion. For the case of significantly elevated Total Water Levels relative to lower dune heights that would result in the predominance of coastal flooding hazards, the Storm Hazard M atrix encapsulates the existing Sallenger (2000) 'Storm Impact Scale'. However, for more elevated dune systems along coastlines where energetic storm waves cause greater impact than the associated storm surge, practical experience is that beach and dune erosion hazards dominate, that are not sufficiently captured by a TWL-based approach alone. Importantly, separately classifying the flooding (vertical) and erosion (horizontal) hazard regimes can provide additional insight by distinguishing between the severity of localized impacts. As illustrated in Figure 5 and the accompanying Figure 6 and Figure 7, considering coastal flooding and beach erosion hazards separately as well as in combination can result in an enhanced understanding of the nature, magnitude and alongshore variation of a storm's impact along the coast.

In the broader context, categorising and distinguishing storm hazards that threaten sandy coastlines is well recognized as an essential step in natural disaster risk reduction, informed decision-making and coordinated mitigation actions (Weichselgartner and Pigeon, 2015). The Sendai Framework for Disaster Risk Reduction (UNDRR, 2015) recommends several actions for countries to prioritize, which include understanding disaster risk and enhancing disaster preparedness for effective response. Present efforts around the world on applying these approaches to reduce the risk of coastal disasters (e.g. van Dongeren et al., 2018) has identified that additional tools are needed. The Storm Hazard Matrix proposed here is one approach that can now be applied as a practical tool to distinguish and categorize coastal hazards within the context of strategic planning and risk assessment.

In parallel to this, there is a growing focus and effort internationally on early warning along coastlines that are impacted by damaging coastal storms (Ciavola et al., 2011; Barnard et al., 2014; Ciavola and Coco, 2018; van Dongeren et al., 2018). Operational early warning systems (EWS) with a typical 7-day forecast lead time all require careful consideration of an appropriate hazards classification and ranking scale that is suitable to inform emergency preparedness and public safety warnings. In particular, it is a priority to establish efficient, practicable methods that can be readily applied to forecast localized hazards spanning regions of several 100 's $\mathrm{km}$ of coastline. At the present time, more complex and 
physics-based numerical modeling approaches are computationally prohibitive for this purpose. Application of the Storm Hazard M atrix in this context of operational EWS is a current focus of active investigation.

While the relative simplicity of the Storm Hazard M atrix developed and presented here results in an approach that can be readily adopted across differing coastal regions, it is necessary to recognise that this is predicated on the availability of morphological and hydrodynamic information. In particular, up-to-date beach and dune topography is a requirement, especially for dynamic beach and dune systems where antecedent morphological conditions are crucial to determining storm impacts (Beuzen et al., 2019b). Encouragingly, the regular collection of airborne Lidar of the more slowly evolving back-beach and dune area is becoming increasingly routine for many coastal regions around the world (e.g. Sallenger et al., 2005; Zhang et al., 2005; M iddleton et al., 2013; Burvingt et al., 2016; Kim et al., 2017). Combined with more recent advances in the use of satellite-derived methods to rapidly determine the pre-storm position of the shoreline (i.e., beach width) and beach face slope (e.g. Vos et al., 2019), the near real-time integration of these sources of beach and dune topographic information is presently being explored. Similarly, Several global models (e.g. NOAA Wavewatch III, Deltares Global Flood Forecasting and Information System, Aviso Global Tide FES model) can provide deepwater wave, tide and surge information along coastlines where these are not measured locally, however the estimation of wave setup and runup is still likely to be dependent on calculations of sitespecific wave transformation in the nearshore (da Silva et al., 2020). Probabilistic methods such as ensembles (Beuzen et al., 2019a), M onte Carlo (Davidson et al., 2017) and Bayesian networks (Beuzen et al., 2018) are practical approaches that enable uncertainty in local morphology and storm hydrodynamics to be appropriately considered. As the availability of routine coastal observations spanning regional scales continues to expand and modelling tools improve, implementation of the Storm Hazard Matrix within the context of operational Early Warning Systems has the potential to deliver forecasts of coastal storm hazards spanning both wave-dominated and surge-dominated coasts.

\section{Acknowledgements}

This study was funded by the Australian Research Council (LP170100161). The first author is supported by a UNSW Scientia PhD Scholarship and the Australian Government Research Training Program. Data collection during the NSW 2016 East Coast Low was funded by the Australian Research Council (DP150101339) with assistance by the NSW Office of Environment and Heritage (OEH) Coastal Processes and Responses Node and Northern Beaches Council. NSW Tide and waverider buoy data were provided by the NSW Department of Industry, Planning and Environment (DPIE) and managed 
by M anly Hydraulics Laboratory. Jason M iddleton and Peter M umford conducted the NSW Airborne Lidar survey and Lidar data pre-processing. For the Santa Rosa Island Hurricane Ivan event, Lidar data was collected through a joint program between USGS, NASA and USACE. Kara Doran (USGS) kindly provided the processed survey dataset and David Thompson (USGS) provided hydrodynamic modelling results. Tom Beuzen (now at UBC) is acknowledged for his guidance with the processing of the NSW and Santa Rosa Lidar and hydrodynamic datasets.

\section{References}

Armaroli, C., Ciavola, P., Perini, L., Calabrese, L., Lorito, S., Valentini, A., M asina, M., 2012. Critical storm thresholds for significant morphological changes and damage along the EmiliaRomagna coastline, Italy. Geomorphology, Thresholds for storm impacts along European coastlines 143-144, 34-51. https:// doi.org/10.1016/j.geomorph.2011.09.006

Armaroli, C., Duo, E., 2018. Validation of the coastal storm risk assessment framework along the Emilia-Romagna coast. Coastal Engineering, RISC-KIT: Resilience-increasing Strategies for Coasts - Toolkit 134, 159-167. https:// doi.org/10.1016/j.coastaleng.2017.08.014

Barnard, P.L., van Ormondt, M., Erikson, L.H., Eshleman, J., Hapke, C., Ruggiero, P., Adams, P.N., Foxgrover, A.C., 2014. Development of the Coastal Storm M odeling System (CoSM oS) for predicting the impact of storms on high-energy, active-margin coasts. Natural Hazards 74, 1095-1125. https://doi.org/10.1007/s11069-014-1236-y

Beuzen, T., Goldstein, E.B., Splinter, K.D., 2019a. Ensemble models from machine learning: an example of wave runup and coastal dune erosion. Natural Hazards and Earth System Sciences 19, 2295-2309. https:// doi.org/10.5194/nhess-19-2295-2019

Beuzen, T., Harley, M .D., Splinter, K.D., Turner, I.L., 2019b. Controls of Variability in Berm and Dune Storm Erosion. Journal of Geophysical Research: Earth Surface 124, 2647-2665. https://doi.org/10.1029/2019JF005184

Beuzen, T., Splinter, K.D., M arshall, L.A., Turner, I.L., Harley, M .D., Palmsten, M .L., 2018. Bayesian Networks in coastal engineering: Distinguishing descriptive and predictive applications. Coastal Engineering 135, 16-30. https:// doi.org/10.1016/j.coastaleng.2018.01.005

Burvingt, O., Masselink, G., Russell, P., Scott, T., 2016. Beach response to consecutive extreme storms using LiDAR along the SW coast of England. Journal of Coastal Research 1, 10521056. https://doi.org/10.2112/SI75-211.1

Castelle, B., M arieu, V., Bujan, S., Splinter, K.D., Robinet, A., Sénéchal, N., Ferreira, S., 2015. Impact of the winter 2013-2014 series of severe Western Europe storms on a double-barred sandy coast: Beach and dune erosion and megacusp embayments. Geomorphology 238, 135-148. https://doi.org/10.1016/j.geomorph.2015.03.006

Ciavola, P., Coco, G. (Eds.), 2018. Coastal storms: processes and impacts, Hydrometeorological Extreme Events. John Wiley \& Sons, Inc, Chichester, West Sussex. 
Ciavola, P., Ferreira, O., Haerens, P., Van Koningsveld, M., Armaroli, C., Lequeux, Q., 2011. Storm impacts along European coastlines. Part 1: The joint effort of the M ICORE and ConHaz Projects. Environmental Science \& Policy, Adapting to Climate Change: Reducing Waterrelated Risks in Europe 14, 912-923. https:// doi.org/10.1016/j.envsci.2011.05.011

Cohn, N., Ruggiero, P., García-M edina, G., Anderson, D., Serafin, K.A., Biel, R., 2019. Environmental and morphologic controls on wave-induced dune response. Geomorphology 329, 108-128. https://doi.org/10.1016/j.geomorph.2018.12.023

da Silva, P.G., Coco, G., Garnier, R., Klein, A.H.F., 2020. On the prediction of runup, setup and swash on beaches. Earth-Science Reviews 103148. https://doi.org/10.1016/j.earscirev.2020.103148

Davidson, M .A., Turner, I.L., Splinter, K.D., Harley, M.D., 2017. Annual prediction of shoreline erosion and subsequent recovery. Coastal Engineering 130, 14-25. https://doi.org/10.1016/j.coastaleng.2017.09.008

Department of Environmental Protection, State of Florida (DEP Florida), 2004. Hurricane Ivan. Beach and Dune Erosion and Structural Damage Assessment and Post-Storm Recovery Plan for the PanHandle Coast of Florida.

Dolan, R., Davis, R.E., 1992. An Intensity Scale for Atlantic Coast Northeast Storms. Journal of Coastal Research 8, 840-853.

Doran, K.S., Stockdon, H.F., Long, J.W., Plant, N.G., 2019. Forecasts of coastal-change hazards, in: Coastal Sediments 2019. World Scientific, pp. 1400-1410. https://doi.org/10.1142/9789811204487_0122

Harley, M.D., 2018. Coastal Storm Definition, in: Ciavola, P., Coco, G. (Eds.), Coastal Storms: Processes and Impacts, Hydrometeorological Extreme Events. John Wiley \& Sons Ltd, pp. 122.

Harley, M.D., Turner, I.L., Kinsela, M.A., Middleton, J.H., M umford, P.J ., Splinter, K.D., Phillips, M.S., Simmons, J.A., Hanslow, D.J., Short, A.D., 2017. Extreme coastal erosion enhanced by anomalous extratropical storm wave direction. Scientific Reports 7, 6033. https://doi.org/10.1038/s41598-017-05792-1

Harley, M.D., Turner, I.L., Short, A.D., Ranasinghe, R., 2009. An empirical model of beach response to storms - SE Australia. Presented at the Coasts and Ports 2009: In a Dynamic Environment, Wellington, N.Z, pp. 600-606.

Harley, M .D., Valentini, A., Armaroli, C., Ciavola, P., Perini, L., Calabrese, L., Marucci, F., 2012. An Early Warning System For The On-line Prediction Of Coastal Storm Risk On The Italian Coastline. Coastal Engineering Proceedings 1, 77. https://doi.org/10.9753/icce.v33.management. 77

Harley, M.D., Valentini, A., Armaroli, C., Perini, L., Calabrese, L., Ciavola, P., 2016. Can an earlywarning system help minimize the impacts of coastal storms? A case study of the 2012 Halloween storm, northern Italy. Natural Hazards and Earth System Sciences 16, 209-222. https://doi.org/10.5194/nhess-16-209-2016 
Hillier, J.K., Matthews, T., Wilby, R.L., M urphy, C., 2020. Multi-hazard dependencies can increase or decrease risk. Nature Climate Change 10, 595-598. https:// doi.org/10.1038/s41558-020$0832-y$

Houser, C., Hapke, C., Hamilton, S., 2008. Controls on coastal dune morphology, shoreline erosion and barrier island response to extreme storms. Geomorphology 100, 223-240. https://doi.org/10.1016/j.geomorph.2007.12.007

Jimenez, J.A., Armaroli, C., Bosom, E., 2018. Preparing for the Impact of Coastal Storms: A Coastal M anager-oriented Approach, in: Ciavola, P., Coco, G. (Eds.), Coastal Storms: Processes and Impacts, Hydrometeorological Extreme Events. John Wiley \& Sons Ltd, pp. 217-240.

Judge, E.K., Overton, M.F., Fisher, J.S., 2003. Vulnerability Indicators for Coastal Dunes. Journal of Waterway, Port, Coastal, and Ocean Engineering 129, 270-278. https://doi.org/10.1061/(ASCE)0733-950X(2003)129:6(270)

Kim, H., Lee, S.B., M in, K.S., 2017. Shoreline change analysis using airborne LiDAR bathymetry for coastal monitoring. Journal of Coastal Research 33, 269-273. https:// doi.org/10.2112/SI79055.1

Kriebel, D., Dalrymple, R., Pratt, A., Sakovich, V., 1996. Shoreline risk index for northeasters. Presented at the Proceedings of the Conference on Natural Disaster Reduction, pp. 251-252.

Lerma, A.N., Bulteau, T., Muller, H., Decarsin, C., Gillet, R., Paris, F., Biausque, M., Senechal, N., Castelle, B., 2018. Towards the Development of a Storm Erosion EWS for the French Aquitaine Coast. Journal of Coastal Research 666-670. https:// doi.org/10.2112/SI85-134.1

M cCall, R.T., Van Thiel de Vries, J.S.M., Plant, N.G., Van Dongeren, A.R., Roelvink, J.A., Thompson, D.M., Reniers, A.J.H.M., 2010. Two-dimensional time dependent hurricane overwash and erosion modeling at Santa Rosa Island. Coastal Engineering 57, 668-683. https://doi.org/10.1016/j.coastaleng.2010.02.006

M clnnes, K.L., Hubbert, G.D., 2001. The impact of eastern Australian cut-off lows on coastal sea levels. Meteorological Applications 8, 229-243. https://doi.org/10.1017/S1350482701002110

Mendoza, E.T., Jimenez, J.A., Mateo, J., 2011. A coastal storms intensity scale for the Catalan sea (NW Mediterranean). Natural Hazards and Earth System Sciences 11, 2453-2462. https://doi.org/10.5194/nhess-11-2453-2011

Mentaschi, L., Vousdoukas, M.I., Pekel, J.-F., Voukouvalas, E., Feyen, L., 2018. Global long-term observations of coastal erosion and accretion. Scientific Reports 8, 12876. https://doi.org/10.1038/s41598-018-30904-w

Middleton, J.H., Cooke, C.G., Kearney, E.T., M umford, P.J., M ole, M .A., Nippard, G.J., Rizos, C., Splinter, K.D., Turner, I.L., 2013. Resolution and Accuracy of an Airborne Scanning Laser System for Beach Surveys. J. Atmos. Oceanic Technol. 30, 2452-2464. https://doi.org/10.1175/JTECH-D-12-00174.1 
M iller, J.K., Livermont, E., 2009. A predictive index for wave and storm surge induced erosion Presented at the Proceedings of the Coastal Engineering Conference, pp. 4143-4153. https://doi.org/10.1142/9789814277426_0344

M orton, R.A., Paine, J.G., Gibeaut, J.C., 1994. Stages and Durations of Post-Storm Beach Recovery, Southeastern Texas Coast, U.S.A. Journal of Coastal Research 10, 884-908.

NSW Department of Justice, Office of Emergency Management (NSW DJOEM ), 2016. State Recovery Co-ordinator Report June 2016 East Coast Low.

Phillips, M.S., Blenkinsopp, C.E., Splinter, K.D., Harley, M .D., Turner, I.L., 2019. M odes of berm and beachface recovery following storm reset: observations using a continuously scanning lidar. Journal of Geophysical Research: Earth Surface 124, 720-736. https://doi.org/10.1029/2018JF004895

Plant, N.G., Stockdon, H.F., 2012. Probabilistic prediction of barrier-island response to hurricanes. Journal of Geophysical Research: Earth Surface 117. https:// doi.org/10.1029/2011JF002326

Pollard, J., Spencer, T., Brooks, S., 2019. The interactive relationship between coastal erosion and flood risk. Progress in Physical Geography: Earth and Environment 43, 574-585. https://doi.org/10.1177/0309133318794498

Roelvink, D., Reniers, A., van Dongeren, A., van Thiel de Vries, J., M cCall, R., Lescinski, J., 2009. Modelling storm impacts on beaches, dunes and barrier islands. Coastal Engineering 56, 1133-1152. https://doi.org/10.1016/j.coastaleng.2009.08.006

Rueda, A., Vitousek, S., Camus, P., Tomás, A., Espejo, A., Losada, I.J., Barnard, P.L., Erikson, L.H., Ruggiero, P., Reguero, B.G., M endez, F.J., 2017. A global classification of coastal flood hazard climates associated with large-scale oceanographic forcing. Scientific Reports 7, 5038. https://doi.org/10.1038/s41598-017-05090-w

Sallenger, A.H., 2000. Storm Impact Scale for Barrier Islands. Journal of Coastal Research 16, 890895.

Sallenger, A.H., Wright, C.W., Lillycrop, J., 2005. Coastal impacts of the 2004 hurricanes measured with airborne LiDAR: initial results. Shore \& Beach 73, 10-15.

Serafin, K.A., Ruggiero, P., Barnard, P.L., Stockdon, H.F., 2019. The influence of shelf bathymetry and beach topography on extreme total water levels: Linking large-scale changes of the wave climate to local coastal hazards. Coastal Engineering 150, 1-17. https://doi.org/10.1016/j.coastaleng.2019.03.012

Stockdon, H.F., Holman, R.A., Howd, P.A., Sallenger, A.H., 2006. Empirical parameterization of setup, swash, and runup. Coastal Engineering 53, 573-588. https://doi.org/10.1016/j.coastaleng.2005.12.005

Stockdon, H.F., Sallenger, A.H., Holman, R.A., Howd, P.A., 2007. A simple model for the spatiallyvariable coastal response to hurricanes. Marine Geology 238, 1-20. https://doi.org/10.1016/j.margeo.2006.11.004 
Stokes, K., Poate, T., M asselink, G., 2019. Development of a real-time, regional coastal flood warning system for southwest england, in: Coastal Sediments 2019. World Scientific, pp. 1460-1474. https://doi.org/10.1142/9789811204487_0127

United Nations International Strategy for Disaster Reduction (UNISDR), 2006. Global Survey of Early Warning Systems: An Assessment of Capacities, Gaps and Opportunities Towards Building a Comprehensive Global Early Warning System for all Natural Hazards. United Nations International Strategy for Disaster Reduction, Geneva, Switzerland.

United Nations Office for Disaster Risk Reduction (UNDRR), 2015. Sendai Framework for Disaster Risk Reduction 2015 - 2030. Geneva, Switzerland.

Van der M eer, J.W., Allsop, N.W.H., Bruce, T., De Rouck, J., Kortenhaus, A., Pullen, T., Schüttrumpf, H., Troch, P., Zanuttigh, B., 2018. EurOtop. Manual on wave overtopping of sea defences and related structures. An overtopping manual largely based on European research, but for worldwide application.

van Dongeren, A., Ciavola, P., M artinez, G., Viavattene, C., Bogaard, T., Ferreira, O., Higgins, R., M cCall, R., 2018. Introduction to RISC-KIT: Resilience-increasing strategies for coasts. Coastal Engineering, RISC-KIT: Resilience-increasing Strategies for Coasts - Toolkit 134, 2-9. https://doi.org/10.1016/j.coastaleng.2017.10.007

Vos, K., Splinter, K.D., Harley, M.D., Simmons, J.A., Turner, I.L., 2019. CoastSat: A Google Earth Engine-enabled Python toolkit to extract shorelines from publicly available satellite imagery. Environmental M odelling \& Software 104528. https://doi.org/10.1016/j.envsoft.2019.104528

Weichselgartner, J., Pigeon, P., 2015. The Role of Knowledge in Disaster Risk Reduction. Int J Disaster Risk Sci 6, 107-116. https:// doi.org/ 10.1007/s13753-015-0052-7

Whalstrom, M., Guha-Sapir, D., 2015. The Human Cost of Weather-Related Disasters 1995-2015. Geneva, Switzerland: UNISDR.

Winter, G., Storlazzi, C., Vitousek, S., van Dongeren, A., M cCall, R., Hoeke, R., Skirving, W., M arra, J., Reyns, J., Aucan, J., Widlansky, M., Becker, J., Perry, C., M asselink, G., Lowe, R., Ford, M., Pomeroy, A., M endez, F., Rueda, A., Wandres, M., 2020. Steps to Develop Early Warning Systems and Future Scenarios of Storm Wave-Driven Flooding Along Coral Reef-Lined Coasts. Front. Mar. Sci. 7. https:// doi.org/10.3389/fmars.2020.00199

Zhang, K., Douglas, B., Leatherman, S., 2002. Do Storms Cause Long-Term Beach Erosion along the U.S. East Barrier Coast? The Journal of Geology 110, 493-502. https://doi.org/10.1086/340633

Zhang, K., Whitman, D., Leatherman, S., Robertson, W., 2005. Quantification of beach changes caused by Hurricane Floyd along Florida's Atlantic coast using airborne laser surveys. Journal of Coastal Research 21, 123-134. https://doi.org/10.2112/02057.1 